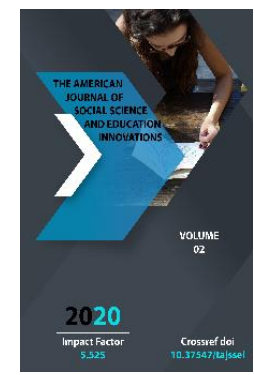

\title{
Challenges Of Creativity And Competence Of Children In Early Childhood Education
}

\author{
Rizaeva Munisaxon Mahkamovna
}

A Senior Teacher Of The Department Of "Musical Education Till School" Of The Institute of Retraining And Preparing Of Heads And Specialists Of Residents Of Kindergarten, Uzbekistan

\section{ABSTRACT}

Early childhood education institutions focus on preschools, kindergartens, and practical schools that educate young children. A preschool education program has been developed to provide a rich learning experience for children in preschools and to promote healthy growth. Creativity is the foundation of a preschool curriculum and can be defined as a way of creating original things. Preschool teachers need to provide children with materials to stimulate their imagination, provide opportunities to imagine and explain their ideas, value children's individuality, and encourage their different perspectives and also educators should be more attentive and responsible to increase children's different competences that can be related to the education for their future. They should also encourage children to participate in creative games, take care of and appreciate children's new products. It is also important to value children's creativity, and to give children confidence. This study aims to examine the creativity of preschool children. The study used a simple causal design with preand post-test tests involving a single group. Participants consisted of 184 children ( 96 boys, 88 girls) studying in preschools and kindergartens under the Ministry of Education in Ankara during the 20142015 academic year. Forms A and B of the Torrance tests of creative thinking were used as pre- and post-tests. The results showed that the preschool education program had a positive impact on children's creativity.

\section{KEYWORDS}

Creativity, preschool education, preschool education program, competence, confidence, implementation. 


\section{INTRODUCTION}

Preschools focus on preschools, kindergartens, and practical schools that educate young children. A curriculum has been developed to provide a rich learning experience for children in preschools. The goal is to maximize children's motor, socioemotional, linguistic and cognitive development and to enable them to acquire self-care skills and be ready for primary school. One of the main principles of preschool education is to mobilize imagination and creativity in these children. In the pre-school education program of the Ministry of Public Education until 2013, creativity was not considered as an individual direction. However, creativity is the foundation of the curriculum. Children need to express themselves in a variety of unique ways in an environment appropriate to their learning needs and teaching methods. Appropriate facilities should be provided to enable this. All planned activities should support creativity. Therefore, understanding creativity is very important for preschool education. [3, 4] Creation can be called the process of producing original things. It is the development of original ideas and the creation of new products and inventions by the individual. [5] Creation is different in each person, and even the creative processes within each person are different. [6] An important factor in the implementation of creative activities in the preschool education program for preschool children is the availability of appropriate teaching techniques and rich materials. [7] According to Bloomberg (1973), creativity is the sum of abilities in the category of diversity of thinking. These categories are defined as fluency, flexibility, originality, and precision. Fluency is the ability to produce and the number of ideas on a topic. Flexibility is a change in perspective on problems. Originality gives rise to unique ideas. The development details the added ideas. [8] Vygotsky (1962) developed the concept of the proximal developmental zone (ZPD) for early childhood. Accordingly, children experience learning with peers and adults. Collaborative interactions with their peers and adults create opportunities to develop creativity. Therefore, it is very important to provide a creative environment for children by adults at an early age. Children are not afraid to make mistakes and take risks in a creative environment. Children's ideas are respected and their mental attacks are positively received. Therefore, the positive attitude of preschool educators is another factor of creativity. [3, 9, 10, 11] Preschool educators need to consider a number of points to support children's creativity. Preschool educators need to provide rich materials that mobilize children's imaginations, offer children opportunities to dream, express their ideas, value individuality, and encourage different perspectives. They should encourage children to participate in creative games and take care of and appreciate their new products. In addition, they need to value and convince children of their creativity. Studies show that creativity can be improved. Fayzi, Azari, and Maleki [12] studied design settings that improve children's creativity. The study found that a rich environment that encourages children and active participation in children's work, along with natural materials, positively improves children's creativity. Yıldız [13] studied the creative education program with a total of 24 children to study its impact on children's social and cognitive development. In her study with four- to five-year-olds, she presented a creative learning program to 12 children that she identified as an experimental group. As a result of the study, she found significant differences in favor of children who received a creative education program in the 
areas of cognitive development and social development between groups who received a creative education program and those who did not. Cheung [14] studied the effects of creative movement activities applied to preschool children. She attended three kindergartens with 12 children and 3 class teachers who were educated in these kindergartens. She practiced creative movement activities based on four basic principles: introducing a topic, mastering and learning movement skills, expressing creativity, and appreciating performance. Research shows that children's creativity can be supported and improved through creative movement activities. Rizi, Yarmohamadiyan, and Gulami [15] studied with 60 children continuing in kindergarten to determine the impact of group play on creative development in six-year-olds. Of the children, 30 were identified as the experimental group and 30 as the control group. The experimental group was trained through group games, and both groups participated in a post-test after the training program was completed. The results showed that the children's creative performance grew positively as a result of the group play sessions. It was found that children's creative abilities can be developed through team play activities. Alfonso-Benlliure, Melendez, and GarciaBallesteros [16] evaluated the impact of a creative intervention program designed for preschool children. The creative intervention program was applied to 44 children aged 60-71 months who were continuing in kindergarten. The study found that the quality of creativity in children's products has improved due to the creative intervention program. Dzidzevich, Oledzka, and Karvowski [17] studied with 128 children continuing in kindergarten to study the development of creativity in children between the ages of four and six. Children were divided into two groups as experiment and control. They applied a creative doddlebook program to 67 children in the experimental group over a five-week period. According to the study, the doodle-book program positively enhanced the imaginative and creative development of children between the ages of four and six. Garaigordobil and Berrueko [18] explored the impact of a play program applied to preschool children on children's creativity.

According to the study, they found that the play program is effective in developing children's creative behaviors. In addition to implementing creative education programs to develop the creativity of preschool children, activities such as play activities, drama activities, and early literacy activities also improve creativity. It can also be said that a rich stimulating environment created in the classroom and supporting creativity has a positive impact on children's creativity. The study focused on the study of children's creativity in preschools. To this end, the answers to the following sub-questions were sought. Does pre-school education affect children's creativity in terms of the following dimensions? 1. smooth, 2. Originality, 3. Development, 4. Abstraction of headings, 5. Resistance to early closure, 6 . Total number, 7. General rating indicators of creativity, 8. General figure creativity.

\section{MATERIALS AND METHODS}

Information on the MONE 2013 pre-school education program, research design, study group, data collection tool, data collection and analysis are included in this section of the study. In the study, a group of initial test simple experimental designs were used. [19] Effects on this design the experimental process is tested in a single group. The related variable measurements of the subjects are obtained using the same subjects and the same means that were tested before and after the test. If 
the data obtained show a significant difference between the pre- and post-test, this difference is assumed to be related to the performance effect. Information on the research design is given in Table 1. In this context, the Torrance Creative Thinking Test (Form A, Form B) was conducted as a pre- and post-test for one group, and the MOM used the curriculum as a pre-school education procedure until 2013. Table 1. Research design team Pre-test procedure Post-test $\mathrm{G} \quad \mathrm{O}_{1} \times \mathrm{O}_{2}$ Torrance Creative Thinking Test (Form A, Form B) Preschool Education Program of the IOM until 2013 Torrance Creative Thinking Test (Form A, Form B).

An appropriate applied research group was used in selecting the study group. [20] A study group of relevant examples is a selection of individuals and groups that can be easily studied. The researcher can select individuals and groups to easily collect data. As we come to the Data collection tool, Form A and B forms of the Torrance Creative Thinking Test (TCTT), developed by Torrance (1966), were used.General information form: The cover page of Torrance Creative Thinking Tests includes information about the children, name, date of birth. Creative Thinking Tests: It consists of four forms: Oral Form A, Oral Form $B$, Figured Form $A$ and $B$ Form Creative Thinking Tests. Tests that measure creative thinking performance were developed by $E$. Paul Torrance. In the 1966 measurement tool, the figurative form consists of three exercises: drawing; finish the picture; and create a drawing separation other than parallel lines. Figured forms include fluency, originality, processing, abstraction of titles, resistance to premature closure, overall shape, overall creative power rating, and overall figurative creativity factors. The oral form consists of seven subtests, which ask questions, make assumptions about the causes, predict the consequences, improve the product, make extraordinary use, make extraordinary questions and assumptions. Oral form $A$ and $B$ and forms $A$ and $B$ are similar to each other. It is a measurement tool widely used in creative research since 1966 . In our country, the validityreliability and linguistic equivalence studies of $A$ and $B$ forms and oral forms of testing for preschool, primary school, secondary school and adults were conducted by Aslan (1999). In the adaptation studies of the test in Turkey, the program was conducted in all preschool, primary school, middle and adult groups. Effective conclusions have been drawn from the study of language equivalence, reliability, and authenticity. The tests for the validity and reliability of the measuring instrument and a single form was obtained by comparing these three forms. For the Oral form of the test, significant results ranging from $0.64-0.86$ to 0.01 degrees, resulting in 0.01 and 0.05 to 0.50 to 0.96 , were obtained from the figurative form. Achievements and type of training are not yet recorded in the curriculum, teachers plan daily educational activities. The type of activity, the learning process, and the materials may vary depending on the teachers 'opinions and experiences. All teachers need to help children achieve their goals through semistructured sessions. The preschool curriculum is child-centered and focused on learning through discovery. It provides children with opportunities for active planning, practice, coordination, questioning, research, discussion, and production during the learning process. Children's physical environment is flexible to adapt to their family characteristics. It is a spiral training program that allows you to receive and re-execute instructions according to the requirements of the learning process. The curriculum, in which different approaches and models are implemented, is eclectic. It is game-based, emphasizes family upbringing, takes into account universal values, and 
encourages daily life experiences. The topics in the curriculum are tools, not goals. This includes adaptability and multidimensional assessment for children with special needs. The Preschool Curriculum (2013) contains achievements and guidelines for developing creativity. For example, in the field of cognitive development, there is a guide that "offers creative solutions to a problem" to purchase as "Problems Find Solutions". In the area of social and emotional development, it includes the words "Express yourself creatively". In addition, training centers such as blocks, dramatic games, artwork, books, science, music, sand and water are included in the curriculum. These centers also support creativity. For example, for a block center, "This is a center that allows children to see numbers of different sizes, shapes, and colors where they stand and use the relationships between these figures and use their creativity. Building games using different numbers." The lim program includes language, art, drama, music, movement, play, science, math, early literacy, and travel activities. Creativity is planned as an integral part of these educational activities. Targeted achievements related to creativity are placed in the learning process. A variety of activities will help you plan for different accomplishments. The children work in a circle at the beginning and end of the lesson. These activities are not seen as educational activities, but are aimed at increasing children's readiness for lessons and assessing learning experiences. Children play in three to five different educational activities each day, depending on the duration of the classes.

\section{ANALYSIS AND RESULTS}

Data collection. Forms A and Figural B of the Torrance Creative Thinking Tests for the initial tests were applied by the researcher to the new Kindergarten (2014) in September. Children who are engaged in their own educational activities for one semester. During the semester, children will learn forty languages, forty games, forty arts, thirty sciences, thirty movements, thirty math, twenty-five dramas, twenty-five music, twentyfive early literacy activities, and one trip. Forms $A$ and Figural $B$ of the Torrance creative thinking tests for post-tests were applied by the researcher to the same children in the same kindergartens in May (2015).

Data analysis. Data collected from the research team were analyzed using the SPSS package software. First, it was analyzed whether the data obtained showed a normal distribution. According to Shapiro-Wilk's analysis among the results of the normalcy test, the data showed a normal distribution. Therefore, a "dual t-test ttest" was used, which was one of the parametric tests and was suitable for designing a single subject, and the significance level was 0.05 .

\section{RESULTS}

The study group included a total of 184 children (96 boys, 88 girls) enrolled in preschools and kindergartens under the Ministry of National Education in Ankara in the 2014-2015 academic year. $41.9 \%$ of children are $66-70$ months of age; $26.0 \%$ between $61-65$ months; $22.3 \%$ at 71 months of age and older; and $9.8 \%$ between 56.8 months. Preschools and kindergartens in different districts included. Findings related to determining the impact of preschool education on children's creativity The study was conducted to examine the creativity of children continuing in preschool. This section of the study included findings from 184 children."Does pre-school education affect children's creativity in terms of fluency, originality, thoroughness, abstraction of titles, 
resistance to premature closure, general performance, general creative strength indicators, general figurative creativity?" Answers to the question were sought. Torrance Creativity Test Figurative Creativity The results of the paired sample t-test to compare the pre- and post-test averages of children in forms $A$ and $B$.

\section{DISCUSSIONS}

The results of the present study indicate that regarding methods of fostering creativity each authority has discussed about the special method or techniques, but generally it can be said that in order to classify and integrate methods, they can be categorized in three classes of techniques of personal creativity, techniques of group creativity, techniques of group -individual creativity. In a general conclusion, with regard to the obtained results, it should be said that, childhood is the first and foremost period of an individual's life, a particular period for development of fundamental and movement skills (Hardy et al., 2010). In this period, the child plays an active role in the learning and understanding structure, and the knowledge that he/she gains during this period, is very crucial and determining (Krosh and Slents, 2010). When children start school, they are eager to learn new things and if they have the required preparations of entering into this movement in the child, certainly enough guarantees for his future successes will be provided. Pre-school and school period are the first stages of the formal education and are a very important behavioral environ-ment for many children. And the more the training quality of this course, the stronger academic period they will have as school children. If the aim of this course is to make children achieve success and skills, it is needed to make a decision regarding their curriculum. The curriculum of this period is considered a product and requires a fundamental review, reconsideration and should have its own content and method. Attention to fostering creativity in preschool and school students is an important issue that has attracted attention of experts and scholars, and has continuously been recommended by them.

\section{CONCLUSION}

The study examined the impact of preschool education on children's creativity. The results were limited to children from Ankara. On the other hand, the achievements and types of activities defined by the MNM must be applied to all teachers. In this study, Forms A and B of the Torrance Creativity Test were applied to 184 children enrolled in preschools and kindergartens under the Ministry of National Education in 2014-2015. For 20 weeks between the two tests, the Ministry of Public Education's Preschool Curriculum (2013) was conducted by preschool educators five days a week. The results showed that the curriculum has a positive effect on children's creative abilities. The results of research conducted by several educators, support the results of this study, preschool education is positive for children's creativity affecting. In conclusion, preschool education improves children's creativity in a positive way. The recommendations developed based on the results obtained are given below.

- The effectiveness of the curriculum was assessed with children attending preschools and kindergartens in Ankara. Therefore, it can be applied to children receiving education in different regions.

- Studies can be conducted to determine the attitudes, beliefs, and practices of preschool teachers about the creativity. 
- No control group was used in this study. Control group-designs can be planned in future studies.

- In this study, no persistence study was conducted. Persistence studies can be conducted in order to understand whether the creativity skills acquired in the preschool period are maintained in the subsequent ages.

\section{REFERENCES}

1. MoNe. Ministry of National Education Regulation on Pre-School Education and Primary Education Institutions, Official Newspaper, 2014, Online available from http://www.resmigazete.gov.tr/eskiler/20 14/07/20140726-4.htm.

2. Nasirov U.F., Ochilov Sh.A., UmirzoqovA.A. Analysis of Development of Low-Power and Man-Made Gold Deposits// International Journal of Academic and Applied Research (IJAAR)ISSN: 2643-9603 Vol. 4, Issue 4, April - 2020, Pages: 7174.http://ijeais.org/wpcontent/uploads/2020/4/IJAAR200414.pdf

3. Umirzoqov A.A., Jurayev S.J., KaramanovA.N. Economic and mathematical modeling of rational development of small-scale and manmade gold deposits// International Journal of Academic and Applied Research (IJAAR), Vol. 4, Issue 4, April 2020, Pages: 75-77.

http://ijeais.org/wpcontent/uploads/2020/4/IJAAR200415.pdf

4. HayitovO.G.,UmirzoqovA.A.,Iskandarov J.R., Suvanov F.R. Prospects for the industrial use of coal in the world and its process of reproducing//Novateur Publication's JOURNALNX- A Multidisciplinary Peer Reviewed Journal, Volume 6, Issue 5, may-2020, Pages:240247.

https://journalnx.com/journalarticle/20151009
5. KazakovA.N., UmirzoqovA.A., RadjabovSh.K., MiltiqovZ.D. Assessment of the Stress-Strain State of a Mountain Range// International Journal of Academic and Applied Research (IJAAR), Vol. 4 - Issue 6 (June - 2020),Pages:17-21. http://www.ijeais.org/ijamsr/index.php/ija msr-4-6-2020/

6. Nasirov U.F., Ochilov Sh.A., Umirzoqov A.A. Theoretical Calculation of the Optimal Distance between Parallel-close Charges in the Explosion of High Ledges// Journal of Advanced Research in Dynamical and Control Systems - JARDCS, Vol. 12,07special issue, 2020, Pages: 2251-2257. https://www.jardcs.org/abstract.php?id=5 778

7. Umirzoqov A.A., Karamanov A. N., Radjabov Sh. K. Study of the feasibility of using intermediate buffer temporary warehouses inside the working area of the Muruntau quarry// International Journal of Engineering and Information Systems (IJEAIS), Vol. 4, Issue 8, August - 2020, Pages 140-142.

http://www.ijeais.org/ijeais/index.php/ijea is-4-8-2020/

8. Khayitov O.G', Umirzoqov A.A.,Bekmuratov A.O. Small Torch Progress In Prospects Gold Mining In Improving Countries// The American Journal of Interdisciplinary Innovations and Research, 2(09), 65-72. https://doi.org/10.37547/tajiir/Volume02Iss ueo9-11.

https://usajournalshub.com/index.php/taji ir/article/view/1027

9. A. S. Honig. Promoting Creativity in Young Children, Paper Presented at The Annual Meeting of The Board of Advisors for Scholastic, New York, 2000.

10. M. D. Prieto, J. Parra, M. Ferrando, C. Ferrandiz, M. R. Bermejo, C. Sanchez. Creative abilities in early childhood, Journal of Early Childhood Research, Vol. 4, No. 3, 277-290, 2006.

11. G. Duman. SanatEtkinliğiPlanlama, UygulamaveDeğerlendirme. N. Aral, G. 
Duman

(Ed.)

in

ÇocuklardaSanatveYaratıcılık. 7th Edition, Nobel Yayıncılık, Ankara. 2018.

12. M. Faizi, A. K. Azari, S. N. Maleki. Design principles of residental spaces to promote children's creativity, Procedia 658 Investigating the Creativity of Children in Early Childhood Education Institutions Social and Behavioral Sciences, Vol.35, 468-474, 2012.

13. F. Ü. Yıldız. The Effects of 'programs of experimental creativeness' on the social and cognitive developments of 4-5 aged children, Unpublished Master's Thesis, Konya: Selçuk University Institute of Social Sciences Department of Child Development and Education, 2000.

14. R. H. P. Cheung. Designing movement activities to develop children's creativity in early childhood education, Early Child Development and Care, Vol. 180, No. 3, 377-385, 2010.

15. C. B. Rizi, M. H. Yarmohamadiyan, A. Gholami. The effect group plays on the development of the creativity of six-year children, Procedia Social and Behavioral Sciences, Vol.15, 2137-2141.

16. V. Alfonso-Benlliure, J. C. Melendez, M. Garcia-Ballesteros. Evaluation of a creativity intervention program for preschoolers, Thinking Skills and Creativity, Vol. 10, 112- 120, 2013.

17. D. Dziedziewicz, D. Oledzka, M. Karwowski. Developing 4-to 6-year-old children's figural creativity using a doodlebook program, Thinking Skills and Creativity, Vol.9, 85-95, 2013.

18. M. Garaigordobil, L. Berrueco. Effects of a play program on creative thinking of preschool children, The Spain Journal of Psychology, Vol.14, No.2, 608-618, 2011.

19. Ş. Büyüköztürk, E. KılıçÇakmak, Ö. E. Akgün, Ş. Karadeniz, F. Demirel. Scientific Research Methods (22nd edition), PegemAkademi, Ankara. 2016.

20. V. Sönmez, F. G. Alacapınar. Illustrated Scientific Research Methods (4th edition), Anı Yayıncılık, Ankara, 2016. 